\title{
CHARACTERISTICS OF LICHEN PLANUS IN PATIENTS ATTENDING A TERTIARY CARE HOSPITAL IN BANGLADESH
}

\author{
MAHMUD MM ${ }^{1}$, KHANDKER L ${ }^{2}$, SULTANA A ${ }^{2}$, HOSSAIN MS ${ }^{3}$, RAHMAN MM ${ }^{4}$, HOSSAIN MZ ${ }^{5}$
}

\begin{abstract}
Background: Lichen planus is a common, pruritic, inflammatory disease of the skin, mucous membranes, nail and hair follicles. Recurrences are more common and cases of squamous cell carcinoma of the skin occurring on lichen planus have been reported.

Objective: To find out the characteristics of lichen planus attending in a tertiary care hospital. Methods: A cross-sectional study was carried out for a period from July 2009 to June 2010 in the department of Dermatology and Venereology, Bangabandhu Sheikh Mujib Medical University (BSMMU), Dhaka, Bangladesh. Thirty-seven patients of lichen planus were assigned. Purposive type non-probability sampling technique was followed in this study. By face to face interview and also from clinical record data were collected from the patients.

Results: The mean age of the patients was $36 \pm 6.6$ years and highest percentage of patients, 21(56.8\%) were in between the 30-40 years old, 33(89.2\%) had higher secondary level of education and more than half the patients 21(56.8\%) had monthly family income less than 10,000 taka. It was found that and majority of patients 32(86.5\%) were male, two thirds of patients 24(64.9\%) were married and 29(78.4\%) were service holders. It was found that about half of the patients 18(48.6\%) had complaints of itching, maximum 12(32.4\%) had involvement of shin area and 21(56.8\%) suffered for a duration of 1 to 11 months. Regarding clinical findings, majority of papular eruption was moderate type in 19(51.4\%) cases, moderate type scaly lesion was 20(54.1\%) cases and moderate type pigmentation was in 23(62.2\%) cases.
\end{abstract}

Key words: Lichen planus, clinical profile, epidemiological profile.

J Dhaka Med Coll. 2012; 21(2) : 156-159.

\section{Introduction}

Lichen planus is a common pruritic, inflammatory disease of the skin, mucous membranes, nail and hair follicles. The primary lesions of lichen planus are characteristic, almost pathognomic, small, violaceous, flattopped, polygonal papule. The surface is glistening, dry with scant adherent scales. On the surface gray or white puncta or streaks (Wickham striae) cross the lesions. Dermoscopy may enhance the visualization of lichen planus lesions. Koebner phenomenon occurs in lichen planus. Pruritus is often prominent in lichen planus. Most patients react to the itching of lichen planus by rubbing rather than scratching. There is a predilection for the flexor wrists, trunk, medial thighs, shins, dorsal hands and glans penis. ${ }^{1}$ At least two-thirds of cases occur between the ages of 30 and 60 years of age. ${ }^{2}$ Nail changes are present in approximately $5-10 \%$. Longitudinal ridging and splitting are most common. Pterygium formation is a characteristic. ${ }^{1}$ Lichen planus may be a cause of twenty nail dystrophy. Association of lichen planus with syphilis, HSV-2, HIV, amebiasis, chronic bladder infection, hepatitis $\mathrm{C}$, Helicobacter pylori or HPV have been reported. ${ }^{3}$ The prevalence of lichen planus is $<1 \%(0.14-0.80 \%)$ worldwide [USA .44\%]. ${ }^{2}$ Lichen planus is an

1. Dr. Md. Mostaque Mahmud, Medical Officer, Department of Skin and Veneral Disease, Sir Salimullah Medial College \& Mitford Hospital, Dhaka

2. Dr. Lubna Khandker, Dr. Abida Sultana, Assistant Professor, Department of Dermatology and Venereology, Bangabandhu Sheikh Mujib Medial Universaity, Dhaka

3. Dr. Md. Shahadat Hossain, Associate Professor, Departent of Physical Medicine, Dhaka Medial College, Dhaka

4. Md. Mostafizur Rahman, Department of Dermatology and Venereology, Dhaka National Medical College Hospital, Dhaka.

5. Dr. Mohammad Zaid Hossain, Assistant Professor of Medicine, Dhaka Medical College, Dhaka

Correspondence: Dr. Md. Mostaque Mahmud, Medical Officer, Department of Skin and Veneral Disease, Sir Salimullah Medial College \& Mitford Hospital, Dhaka, E-mail: drmstq@yahoo.com 
unpredictable disease that typically persists for 1 to 2 years, but which may follow a chronic relapsing course over many years. ${ }^{1}$ The development of lichen planus may be affected by seasonal or environmental factors. Lichen planus may be familial. The familial form tends to be more protracted and severe and presents in erosive, linear or ulcerative patterns or with atypical features affecting young adults and children. ${ }^{2}$ Relapse of disease occurs in 15 percent to 20 percent of cases and tends to occur in the same area as the initial episode. Recurrences are more common and are usually of shorter duration. Rare cases of squamous cell carcinoma of the skin occurring on lichen planus have been reported. ${ }^{1}$

\section{Methods:}

This was a cross sectional study. The study was carried out for a period from July 2009 to June 2010. Data were collected from the department of Dermatology and Venereology, Bangabandhu Sheikh Mujib Medical University (BSMMU), Dhaka, Bangladesh. Patient suffering from lichen planus were selected as study population. Within the period of data collection, 37 patients of lichen planus were assigned. Purposive type non-probability sampling technique was followed in this study. By face to face interview and also from clinical record data were collected from patient. The patient of lichen planus were identified at first. Then clinical conditions of the patient were recorded by me and skin biopsy was done for histopathological examination. Verbal and written consent were taken from the selected patient and were interviewed by asking questions. Questionnaire was developed for collection of relevant information. The questionnaire was including selected parameters related to socio-demographic characteristics of patients, the complaints of patients of lichen planus and clinical characteristics of lichen planus, After collection, all the data were cleaned by checking consistency, edited and were analyzed by software SPSS version 12.0.

\section{Results}

The mean age of the patients was $36 \pm 6.6$ years and their age ranged from 20 to 50 years. Among the 37 patients, highest percentage of patients, $21(56.8 \%)$ were in between the $30-40$ years old, followed by $10(27 \%)$ were 40 to 50 years old and $6(16.2 \%)$ were in between the $20-30$ years old. It was found that out of 37 patients, 33(89.2\%) had higher secondary level of education and $4(10.8 \%)$ had graduation level of education. It was found that more than half the patients $21(56.8 \%)$ had monthly family income less than 10,000 taka and $16(43.2 \%)$ had monthly family income more than 10, 000 taka. The mean monthly family income was $10,432.43$ taka with standard deviation of $4,186.88$ taka (tableI). Majority of patients 32(86.5\%) were male and only $5(13.5 \%)$ were female. Out of 37 patients, two thirds of patients $24(64.9 \%)$ were married and only one third of patient $13(35.1 \%)$ were unmarried. Figure I showed the occupational status of the patients. It was observed that majority of the patients $29(78.4 \%)$ were service holders, 4(10.8) were house wives, and 4(10.8\%) were involved in business.

\section{Table-I}

Distribution of the patient by epidemiological profile $(n=37)$

\begin{tabular}{lc}
\hline Epidemiological profile & Frequency \\
\hline Age(in years) & \\
$20-30$ & $6(16.2)$ \\
$30-40$ & $21(56.8)$ \\
$40-50$ & $10(27)$ \\
Level of educationalHigher & \\
Secondary level & $33(89.2)$ \\
Graduate and above & $4(10.8)$ \\
Monthly income(Tk) & \\
$>10,000$ & $16(43.2)$ \\
$<10,000$ & $21(56.8)$ \\
\hline
\end{tabular}

Figure II showed the distribution of patients according to the complaints. It was observed that about half of the patients $18(48.6 \%)$ had complaints of itching, followed by skin lesions $16(43.2 \%)$ and only $3(8.1 \%)$ had complaints of disfigurement. 


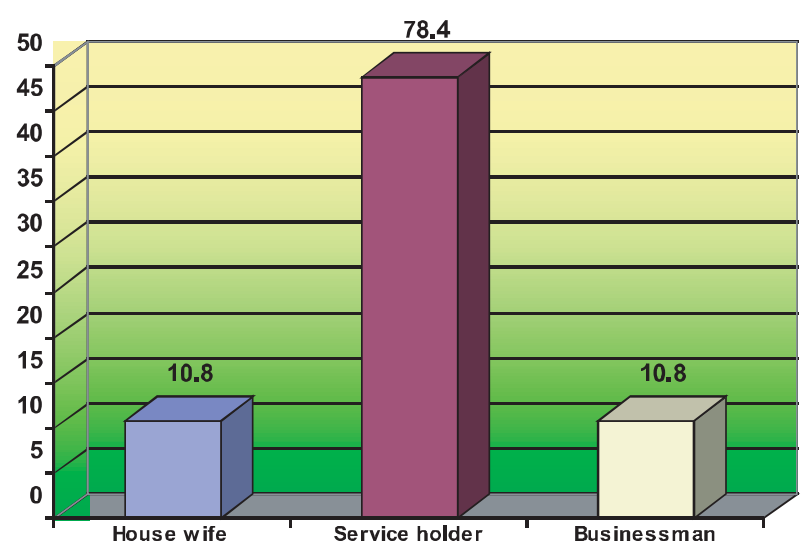

Fig.-I: Distribution of the patient as per occupational status.

Figure III showed distribution of the patients on the basis of site of involvement, maximum $12(32.4 \%)$ had involvement of shin area, followed by fore-arm $9(24.3 \%)$, flexor wrist $7(18.9 \%)$, trunk $4(10.8 \%)$, dorsal hands $3(8.1 \%)$ and involvement of thigh area were $2(5.4 \%)$. It was observed that out of 37 patients, $8(21.6 \%)$ had for a duration of 1 to 3 years, $21(56.8 \%)$ suffered for a duration of 1 to 11 months, $7(18.9 \%)$ for a duration of 1 to 3 weeks and only $1(2.7 \%)$ patient had for a duration of 1 to 6 days (table-II).
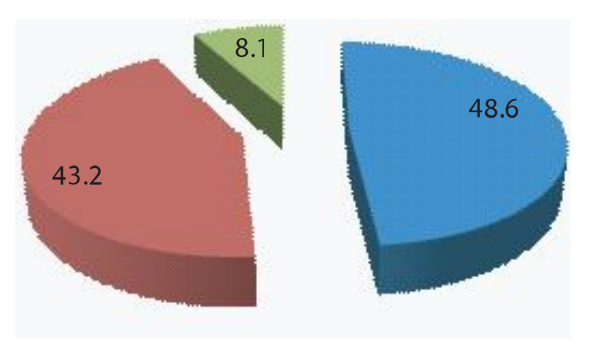

Fig.-II: Distribution of the patient according to the complaints.

Papular eruption was mild in $2(5.4 \%)$ cases, moderate in $19(51.4 \%)$ cases and severe in $16(43.2 \%)$ cases. It was observed that $7(18.9 \%)$ had mild type scaly lesion, 20(54.1\%) had moderate and $10(27 \%)$ had severe type scaly lesion. Regarding grading of pigmentation of the patients, it was observed that pigmentation was moderate in $23(62.2 \%)$ cases, and severe in $14(37.8 \%)$ cases (table-III).

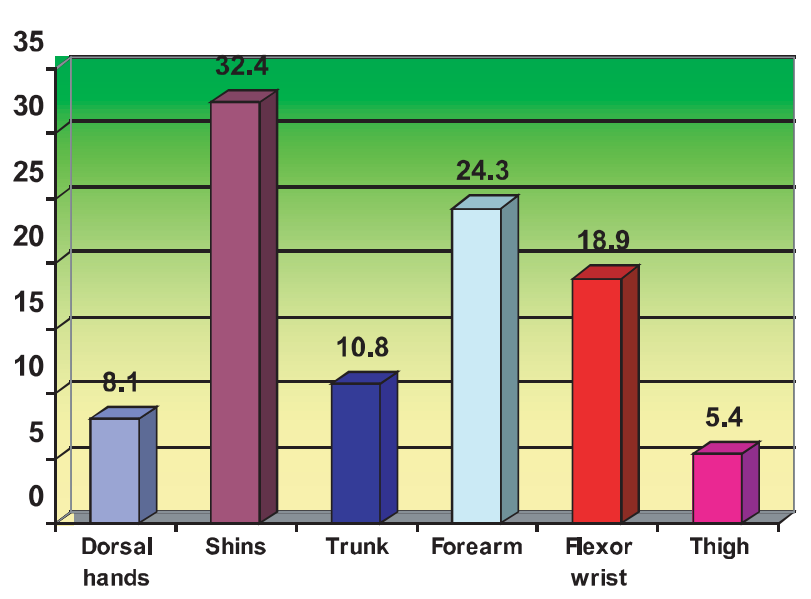

Fig.-III: Distribution of the patient on the basis of site of involvement.

\section{Table II}

Distribution of the patient by duration of lesions $(n=37)$

\begin{tabular}{lc}
\hline Duration of lesions & Frequency \\
\hline 1 to 3 years & $8(21.6 \%)$ \\
1 to 11 months & $21(56.8 \%)$ \\
1 to 3 weeks & $7(18.9 \%)$ \\
1 to 6 days & $1(2.7 \%)$ \\
\hline
\end{tabular}

Table III

Distribution of patients by clinical findings $(n=37)$

\begin{tabular}{lc}
\hline Clinical findings & Frequency \\
\hline Papular eruption & \\
Normal & $0(00 \%)$ \\
Mild & $2(5.4 \%)$ \\
Moderate & $19(51.4 \%)$ \\
Severe & $16(43.2 \%)$ \\
Scaly lesion & \\
Normal & $0(00 \%)$ \\
Mild & $7(18.9 \%)$ \\
Moderate & $20(54.1 \%)$ \\
Severe & $10(27 \%)$ \\
Pigmentation & \\
Normal & \\
Mild & $0(00 \%)$ \\
Moderate & $0(00 \%)$ \\
Severe & $23(62.2 \%)$ \\
\hline
\end{tabular}




\section{Discussion}

This was a cross-sectional type of study, conducted with thirty seven patients. The mean age of the patients was $36 \pm 6.6$ years and their age ranged from 20 to 50 years. Among the patients, highest percentage of patients, $21(56.8 \%)$ were in between the $30-40$ years old, followed by $10(27 \%)$ were 40 to 50 years old and $6(16.2 \%)$ were in between the $20-30$ years old, similar to the study findings of Kanwar et al. ${ }^{4}$ and Xue et al. ${ }^{5}$. It was found that majority of patients $32(86.5 \%)$ were male and only $5(13.5 \%)$ were female, similar to the study finding of Khondker et al. $^{6}$, where $66.66 \%$ were male and $33.33 \%$ were female of lichen planus patient in Dhaka, Bangladesh. Similar study finding were also seen by Nnoruka ${ }^{7}$, Higgins et al. ${ }^{8}$ and Daramola et al. ${ }^{9}$

Regarding the site of the lesion, maximum $12(32.4 \%)$ had involvement of shin area, followed by forearm $9(24.3 \%)$, flexor wrist $7(18.9 \%)$, trunk $4(10.8 \%)$, dorsal hands $3(8.1 \%)$ and involvement of thigh area were $2(5.4 \%)$, similar to the findings of Nnoruka ${ }^{7}$, where limbs involvement were $69.2 \%$ in the African patients of lichen planus and also similar to the study findings of Eisen et al. ${ }^{10}$, Nagao et al. ${ }^{11}$ and Axéll et al. ${ }^{12}$.

It was observed that $21(56.8 \%)$ had been suffering for 1 to 11 months of duration, $8(21.6 \%)$ had been suffering for 1 to 3 years of duration, $7(18.9 \%)$ had been suffering from 1 to 3 weeks and only $1(2.7 \%)$ patient had sufferings for 1 to 6 days, not similar to the study finding of Kanwar et al. ${ }^{4}$, where majority $48.4 \%$ had the disease for 6 months to 3 years. Similar finding were observed by Khondker et al. ${ }^{6}$, where $68 \%$ cases had duration 15 days to 6 months.

\section{Conclusion}

This was a study on a limited number of cases. Future studies must include economical support, then large sample size could be ensured and study finding would be more reliable.

\section{References}

1. James WD, Berger TG, Elston DM. Andrew's Disease of the skin-Clinical Dermatology. $10^{\text {th }}$ ed. USA: Saunders Elsevier; 2006: p. 217-25.

2. Pittelkow MR, Dauod MS. Lichen Planus. In: Wolff K, Goldsmith LA, Katz SI, Gilchrest BA, Paller AS, Leffell DJ. eds. Fitzpatrick's dermatology in general medicine. New York: The McGraw- Hill Companies; 2008: p.244-55.

3. Akdeniz S, Harman M, Atmaca S, Yaldiz M. The management of lichen planus with low- molecular weight heparin (enoxaparin). Int $\mathrm{J}$ Clin Pract 2005; 59(11): 1268-71.

4. Kanwar AJ, Dogra S, Handa S, Parsad D, Radotra BD. A study of 124 Indian patients with lichen planus pigmentosus. Clin Exp Dermatol 2003; 28(5): 481-5.

5. Xue JL, Fan MW, Wang SZ, Chen XM, Li Y, Wang L. A clinical study of 674 patients with oral lichen planus in China. J Oral Pathol Med 2005; 34(8): 467-72.

6. Khondker L, Wahab MA, Khan SI. Profile of lichen planus in Bangladesh. Mymensingh Med J 2010; 19(2): 250-3.

7. Nnoruka EN. Lichen planus in African children: a study of 13 patients. Padiatr Dermatol 2007; 24(5): 495-8.

8. Higgins CR, Handfield-Jones S, Black MM. Erosive, flexural lichen planus - an uncommon variant. Clin Exp Dermatol 1993; 18(2): 169-70.

9. Daramola OO, Ogunbiyi AO, George AO. Evaluation of clinical types of cutaneous lichen planus in anti-hepatitis $\mathrm{C}$ virus seronegative and seropositive Nigerian patients. Int $\mathrm{J}$ Dermatol 2003; 42(12): 933-5.

10. Eisen D, Carrozzo M, Sebastian JVB, Thongprasom K. Number V Oral lichen planus: clinical features and management. Oral Dis 2005; 11(6): 338-49.

11. Nagao T, Ikeda N, Fukano H, Hashimoto S, Shimozato K, Warnakulasuriya S. Incidence rates for oral leukoplakia and lichen planus in a Japanese population. J Oral Pathol Med 2005; 34(9): 532-9.

12. Axéll T, Rundquist L. Oral lichen planus - a demographic study. Community Dent Oral Epidemiol 1987; 15(1): 52-6. 